\title{
The World We Made, Alex McKay's Story from 2050
}

\author{
Belkis BİRDENa
}

Jonathon Porritt, The World We Made, Alex McKay's Story from 2050. Phaidon Press Limited, 2013.

"Hep denedin bep yenildin, olsun gene dene gene yenil, daba iyi yenil."

Samuel Beckett

Jonathon Porritt tarafindan yazılan bu kitap, dünyamızın geleceği hakkında ortaya konulan diğer yapıtlardan, özellikle "çevre"yi konu edinenlerden, felaket senaryolarından uzak, geleceğe dair iyimser bir yaklaşımı benimsemesiyle farklılık göstermektedir. Kitabın dikkat çekici bir yanı da 2050 yılından yazılmış olmasıdır ve bu şekilde olsa da bu kitap kurgusal olmayan yazı türünde yer almaktadır. Kitapta sunulan perspektif, var olan en iyi tahmin ve senaryolara dayandırıldığından, kitabın bilim kurgu türünde olmadığı belirtilebilir.

Kitabın giriş bölümü farklı bir yöntemle anlatılmaktadır. Şöyle ki Alex McKay isimli bir kişi hikayeyi, 31/12/2050 tarihli bir not ile açıklamaktadır: Dünyamızın 2022 ylında gerek ekonomik gerekse çevresel anlamda pek çok soruna sahip olduğunu; ancak ilerleyen 28 yll içinde büyük bir değişim gerçekleştiğini, çoğu ülkenin sorunlarını çözerek daha istikrarlı bir yapıya kavuştuğunu belirtmektedir. Çalışmanın amacının, çöküşün eşiğinden dönen dünyanın, 2050 yılındaki konumuna nasıl geldiğinin hikâyesini anlatmak olduğu vurgulanmaktadır. Ayrıca gelecek nesillere daha iyi bir dünya bırakabilmek için yeni bir anlayış ve sürdürülebilir bir dünya ümidi ile sorunların üstesinden gelinebileceğinin bu eserle kanıtlandığı savunulmaktadır.

Kitaptaki fiziksel ve görsel hususlardan kısaca söz etmek gerekirse; 320 sayfadan oluşan, İngilizce yazılan bu kitap, resim ve illüstrasyonlar ile renkli sayfalar ve el çizimi taslaklarla desteklenmektedir. Kitapta yer alan konu başlıkları şu şekilde özetlenebilir:

Tarım, gıda ve su /Biyoçeşitlilik ve doğal yaşam/ İklim değişikliği/ Ekonomi ve finans Enerji/ Sağlık ve eğitim/ Siyaset ve güvenlik/ Toplum ve şehirler /Teknoloji ve üretim/ Seyahat ve ulaşım. Kitap, bu konu başlıkları ile ilgili 50 retrospektif yazıdan oluşmaktadır. Kitabın sonunda bir ek bölïm, Forum for The Futureb

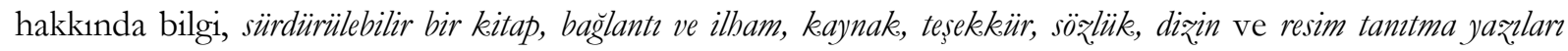
bölümleri yer almaktadır. Kitapta yer alan fütürist fotoğraflar, el çizimi taslaklar ve infografikler aracilığıyla bilginin anlaşıllır, okuyan açısından kolay bir hale geldiğini de söylemek gerekir.

Kitabın adından da anlaşılacağı üzere, açıklamalar Alex McKay adı verilen hayali bir kişi üzerinden yapılmaktadır. Kitap, Alex McKay isminde İngiliz bir tarih öğretmeninin, öğrencilerine önemli tarihsel olayları, teknolojik gelişmeleri ve yaşam tarzındaki dönüşümleri gösterdiği öyküsünü konu almaktadır. 2020'li y1lların başında tarih öğretmenliğine başlayan Alex, son 30 yılda gerçekleşen değişiklikleri anlatmaktadır. Alex, kendisini böyle bir çalışmaya iten nedeni ise 2010'lu ylllarda, dünyada yolunda

\footnotetext{
a Doktora Öğrencisi, Ankara Üniversitesi Tıp Fakültesi, Tıp Tarihi ve Etik Anabilim Dalı $₫$ blksbrdn@gmail.com

b Sürdürülebilirlik üzerine hükümet, iş dünyası ve diğer kuruluşlarla çalışmalar yürüten, bağımsız, kâr amacı gütmeyen bir kuruluştur.

Gönderim tarihi: 09.02.2016 • Kabul tarihi: 10.02.2016
} 
gitmeyen şeylerin olmasına bağlı olarak açıklamaktadır. İkinci Dünya Savaşı'ndan beri insan hayatını ilgilendiren hususların önemini kaybettiğini; bu durum karşısında politikacıların ise, insan hayatı için anlamlı olan şeyler yerine, ekonomik büyüme, kâr1 en üst düzeye çıkarma, küreselleşme, tüketimi arttırma gibi konulara daha fazla zaman harcadığını ve zamanla var olan güçlerini kaybettiklerini açıklamaktadır. 2018 yılında Avrupa'da işsizliğin arttığı ve insanların yaşam standartlarının azaldığı, buna karşı Çin, Hindistan ve Brezilya gibi ülkelerin ekonomilerinin büyüdüğü, bunun yanında bu ülkelerde sosyal, çevresel bazı sorunların baş gösterdiği açıklanmaktadır. Yoksul dünyanın gerçek anlamda yoksul olduğu, zengin dünyanın ise kendini 2000 yllında "binyıl kalkınma hedefleri" denilen bir dizi hedefe teslim ettiği ve bunun sonucunda vatandaşların iş olanaklarının daraldığı, olumsuz sonuçların gün yüzüne çıktığı bir dünya modelini, geçmişte kalan, aşılmış, tarihsel bir olgu olarak tanımlanmaktadır. Bu noktada siyasetçilerin, üzerlerine düşen görevleri yapmadıkları, biriken borçlardan dolayı zor duruma düştükleri, sorunlara çözüm üretmekten yoksun bir halde adeta köşeye sıkıştıkları belirtilmektedir. 2015 yılında ise politikacılardan farklı olarak, sivil toplum kuruluşlan, akademisyenler, girişimciler ve iş dünyası liderlerinin, eski dünya görüşünü bıraktıkları ifade edilmektedir.

Kitap, 21. yüzyılın başında çevresel yıkımla, iklim değişikliğinin olumsuz sonuçlarıyla karşı karşıya kalan dünyamızdan; 2050 yılında adaletli, işbirliklerine açık ve gerçek anlamda sürdürülebilir bir dünyaya geçişin nasıl olduğunu, 9 milyar yaşayanı ile "yeşil" dünyamızın, nasıl bir duruma geldiğini aklımızda canlandırabilmemize firsat vermektedir. Ayrıca bize 2050 yllını, pek çok açıdan ele alan, geniş bir tasvirle sunmaktadır. 2050 yılında dünya öyle bir dünyadır ki; enerjinin \%90'ının yenilenebilir kaynaklardan ve elektriğin \%30’unun güneş enerjisinden karşılandığı, standart bilgisayarların insan beyniyle aynı hızda çalıştı̆̆1, nanoteknoloji, 3D baskı ve biyomimikrinin (Biyomimikri, insanların ihtiyaçlarını karşılamak ve sorunlarını çözmek için doğayı taklit etmenin yollarını inceleyen bir disiplindir.) üretimi dönüştürdüğü, kişisel genomiklerin daha uzun ve sağlıklı bir yaşama elverdiği bir dünya. Zenginin daha yoksul ve mutlu, yoksulun pek çok yönden zengin olduğu bir dünya...

The World We Made isimli bu eseri, sürdürülebilirlik konusunda çözüm aradığımız pek çok sorunda, karşımıza çıkan bir fırsat gibi değerlendirebilir, ayrıca eserin dünyamızın geleceği hakkında yol haritası niteliğinde olduğunu söyleyebiliriz. Kitap, geleceğe dair sunduğu çevre perspektifi ve tüm paydaşların benimsedikleri değerleri gözden geçirmesini sağlaması bakımından son derece önem taşımaktadır. $\mathrm{Bu}$ bakımdan kitabın, artan çevre sorunları karşısında çözüm girişimlerine kaynaklık edebileceği ve bu mücadelede gerek bireylere, sivil toplum kuruluşlarına gerekse topluluklara esin kaynağı olabileceğini vurgulamak gerekir. 